[溶接学会論文集 第 33 巻 第 2 号 p. 180-186 (2015)]

\title{
最弱リンク説に基づいた不均一材破壞勒性試験の確率論的評価方法*
}

\author{
吉津 周平**，中居 寛明***，柴沼 一樹***，粟飯原周二***
}

A Stochastic method to estimate fracture toughness scatter of inhomogeneous materials based on the weakest-link assumption*

by YOSHIZU Shuhei**, NAKAI Hiroaki***, SHIBANUMA Kazuki*** and AIHARA Shuji***

\begin{abstract}
Scatter of fracture toughness of welds is significantly large due to intrinsic nature of cleavage fracture and stochastic nature of fatigue-crack sampling of a local brittle zone. Under such circumstance, it is often desired to predict a distribution of fracture toughness of the local brittle zone, only. The present paper proposes a method of predicting critical CTOD distribution of a specific microstructure, e.g. coarse-grained HAZ, from weld HAZ CTOD tests. The method is based on the weakest-link assumption and uses a likelihood function which is defined by considering critical CTOD values, as well as crack initiation sites. The proposed method was examined by Monte-Carlo simulations.
\end{abstract}

Key Words: Fracture toughness, Multiphase microstructures, Scatter, CTOD, Weibull distribution, Maximum likelihood estimation, Fracture initiation part, Cleavage fracture

1. 緒

言

溶接継手の破壊勒性值には，母材・溶接熱影響部 (HAZ)・溶接金属に亘るミクロ的勒性の分布だけでなく, 強 度の分布や亀裂前縁に沿った各金属組織の配置にも影響す るため, その影響因子は極めて複雑である. 溶接継手の限 界 CTOD 值に及ぼす研究は古く, 1970年頃から英国を中心 に始まった ${ }^{1-4)}$. 我が国でもこの分野で多くの研究がなされ てきた。貝原らは低温用鋼溶接部の限界 CTOD 值のばらつ きを統計的に評価し, それを構造物の信頼性評価に適用し $た^{5,}$. 6) その後, 溶接継手の限界 CTOD 值は局所脆化域に大 きく影響を受けることが明らかとなり，その金属学的な調 查が詳細になされた ${ }^{7,8)}$. 龟裂前縁に占める局所脆化域割合 の影響が実験的に明らかとなり ${ }^{9,}{ }^{10)}$, API 規格に初めて局所 脆化域割合の規定が導入された ${ }^{11)}$. それに応じて, 局所脆 化域が溶接継手の限界 CTODに及ぼす影響について確率論 的に評価する研究が行われた ${ }^{12}$. 局所脆化域以外にも溶接 継手限界 CTOD 值に及ぼす因子は多く，限界 CTOD 值を適 切に評価する試験方法に関する研究が多数行われ ${ }^{13-177}$ ，そ れらの結果が種々の溶接継手破壊勒性試験方法に反映され ている ${ }^{18)}$.

へき開型脆性破壊の発生特性は本質的に大きいばらつき

*受付日 平成27年 3 月 27 日受理日 平成27年 5 月 8 日

**学生員 東京大学工学系研究科 Student Member, School of Engineering, The University of Tokyo

***正 員 東京大学工学系研究科 Member, School of Engineering, The University of Tokyo
を呈するが，溶接継手ではこれに加えてミクロ組織や強度 の不均一性に由来する変動も加わるので, 破壊勒性值の変 動要因が極めて複雑となる。この問題に対しても古くから 研究がなされてきた。佐藤ら ${ }^{19}$ は溶接継手限界 CTOD 值の ばらつきについて確率論的な検討を加え, 材料 $\mathrm{A}, \mathrm{B}, \mathrm{C}$ 単 独の限界 CTOD 值の分布が既知の場合, $\mathrm{A}+\mathrm{B}+\mathrm{C}$ からなる積 層材の限界 CTOD 值の分布を予測する方法を提案し，それ を実験的に検証した。さらに，材料 $\mathrm{A}+\mathrm{B}+\mathrm{C}$ からなる積層 材および材料 A, C 単独の限界 CTOD 值の分布が既知の場 合，材料 B（例えば局所脆化域）の限界 CTOD 值の分布を 予測できることが積層材および意図的に勒性分布を持たせ た溶接金属の CTOD 試験で検証された ${ }^{20)}$.

一方, 脆性破壞発生特性の確率論的様相を説明するため にワイブル応力に基づいたローカルアプローチ占が適用さ れてきた。鋼の限界ワイブル応力の分布は試験片の形状や 寸法に依存しないことが実験的に確認され ${ }^{22}$, この概念が 溶接継手へも適用されるようになったＨAZ の限界 CTOD 值が溶接金属強度によって変化する現象がワイブル応力を 用いて定量的に説明された ${ }^{23)}$. さらに，脆性破壊が局所脆 化域（粗粒 HAZ）のみから発生する場合には，局所脆化域 だけをワイブル応力算定の積分範囲とすることにより，実 験と FEM 解析からその限界ワイブル応力を実験的に求め, それを用いて溶接金属強度が変化した場合の限界 CTOD 值 の変化を予測できることが示された ${ }^{24}$. これらのモデルは すべて脆性破壊発生に対して最弱リンク説を適用したもの であるが，局所脆化域から発生した亀裂のポップインも考 虑すべきとの指摘もある ${ }^{25}$.

上記のように, 材質不均一性が溶接継手の限界 CTOD 值 
に及ぼす影響について検討が進められてきた。しかし，実 際の溶接継手を対象としたCTOD 試験を想定すると，局所 脆化域（粗粒 HAZ），細粒 HAZ，溶接金属，母材のみを独 立に試験することは現実的に困難であり，龟裂前縁にこれ らが分布する試験片を用いた評価が要求される。すなわち, 異なる勒性を有する複数の組織が亀裂前縁に分布している 条件下で，各組織の限界 CTOD を評価することが必要とな る.この評価を可能とする手法は未だ確立されておらず， 溶接継手部の破壊安全性を正確に評価するために重要な課 題である。

以上の背景より，本研究では，まず亀裂前縁に複数の組 織が分布する場合の CTOD 試験の結果より, 各組織の限界 CTOD 值の分布を予測する方法について最弱リンク説に基 づた定式化を提案する。ささらに提案した定式化の妥当性 をモンテカルロ・シミュレーションによって検証する.

\section{2. 評価モデルの定式化}

Fig. 1 に本モデルが対象とする不均一材を模式的に示す. 亀裂前縁に沿って材料 A と B が分布しているものとする.

A，あるいは，B 以外の材料（たとえば母材）が亀裂前縁に 存在していても，そこから脆性破壊が発生しないことが知 られていれば，材料 A と B だけを対象として本モデルが適 用できる。また，材料の種類が 3 ，あるいは，それ以上で も，原理的に本方法を適用できる.このような試験片に対し て $N$ 本の CTOD 試験が実施され, $N$ 個の限界 CTOD 值 $\delta_{c}$ が得られたものとする. 加えて, 脆性破壊発生起点の調査 によって材料 A, または, B のいずれかから破壊が発生し たことが分かっているものとする。ここで，材料 A および

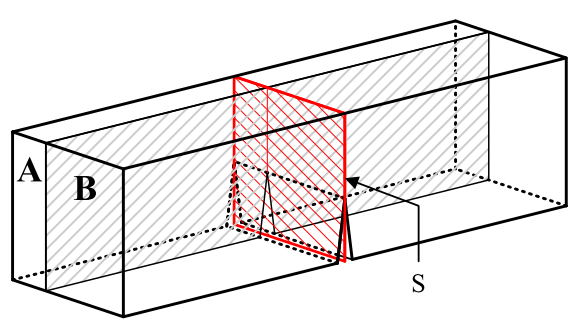

(a) CTOD specimen

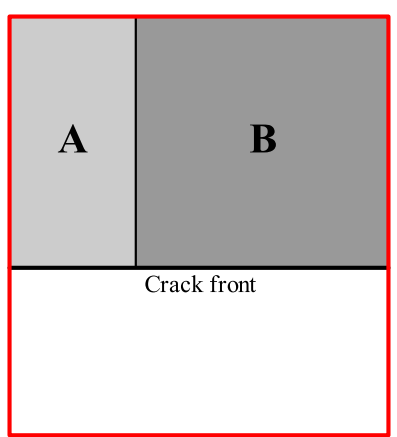

(b) Materials distribution along crack front (close-up of S)

Fig. 1 CTOD specimen having materials distribution
B から発生した試験片の本数を各々， $N_{A}$ および $N_{B}$ とする

$$
N=N_{A}+N_{B}
$$

$i$ 番目の試験片の限界 CTOD 值を $\delta_{c}(i)$ とする. また,$i=1$ $\sim N_{A}$ が材料 A から破壊発生した試験片, $i=\left(N_{A}+1\right) \sim\left(N_{A}+N_{B}\right)$ が材料 B から破壊発生した試験片とする。

ここで, 両材料の限界 CTOD 值の累積確率分布を $F_{A}\left(\delta_{c}\right)$ および $F_{B}\left(\delta_{c}\right)$ と表わす。これらに対応する確率密度関数を 各々, $f_{A}\left(\delta_{c}\right)=d F_{A}\left(\delta_{c}\right) / d \delta_{c}$ および $f_{B}\left(\delta_{c}\right)=d F_{B}\left(\delta_{c}\right) / d \delta_{c}$ と表わ す.ここで注意すべき点は, $F_{A}\left(\delta_{c}\right)$ および $F_{B}\left(\delta_{c}\right)$ は各材料か らなる均一試験片の限界 CTOD 值の分布を表すものではな く，あくまでも Fig. 1 に示すように両材料が配置された試験 片において各材料単独の限界 CTOD 值の確率分布を表わす ものである.すなわち， $F_{A}\left(\delta_{c}\right)$ は，この試験片において仮に 材料 B から脆性破壊が発生することがない場合の材料 A の 限界CTOD值の確率分布を示すものである。

今，ある試験片で材料 $\mathrm{A}$ から脆性破壊が発生して $\delta_{c}(i)$ $\left(1 \leq i \leq N_{A}\right)$ が得られたものとする．最弱リンク説を仮定する と, この事象が発生する確率は次式のように表わすことが できる (Fig. 2).

$$
P(i)=f_{A}\left(\delta_{c}(i)\right) d \delta_{c}\left\{1-F_{B}\left(\delta_{c}(i)\right)\right\}
$$

すなわち，材料 $\mathrm{A}$ が $\delta_{c}(i) \sim\left(\delta_{c}(i)+d \delta_{c}\right)$ の区間で破壊を生 じる一方で，材料 B からは破壊が発生しなかったことを考 慮している。これをすべての試験片に適用する．各試験片 の事象は独立と仮定できるので， $N$ 本の試験結果が生じる 確率は次式で表すことができる.

$P=\prod_{i=1}^{N} P(i)=\prod_{i=1}^{N_{A}}\left[f_{A}\left(\delta_{c}(i)\right) d \delta_{c}\left\{1-F_{B}\left(\delta_{c}(i)\right)\right\}\right] \prod_{i=\left(N_{A}+1\right)}^{\left(N_{A}+N_{B}\right)}\left[f_{B}\left(\delta_{c}(i)\right) d \delta_{c}\left\{1-F_{A}\left(\delta_{c}(i)\right)\right\}\right]$

ここで，改めて尤度関数 $L$ を次式のように定義する.

$$
\begin{aligned}
L & =\prod_{i=1}^{N_{A}}\left[f_{A}\left(\delta_{c}(i)\right)\left\{1-F_{B}\left(\delta_{c}(i)\right)\right\}\right] \prod_{i=\left(N_{A}+1\right)}^{\left(N_{A}+N_{B}\right)}\left[f_{B}\left(\delta_{c}(i)\right)\left\{1-F_{A}\left(\delta_{c}(i)\right)\right\}\right] \\
& =\prod_{i=1}^{N_{A}} f_{A}\left(\delta_{c}(i)\right) \prod_{i=\left(N_{A}+1\right)}^{\left(N_{A}+N_{B}\right)}\left\{1-F_{A}\left(\delta_{c}(i)\right)\right\} \prod_{i=\left(N_{A}+1\right)}^{\left(N_{A}+N_{B}\right)} f_{B}\left(\delta_{c}(i)\right) \prod_{i=1}^{N_{A}}\left\{1-F_{B}\left(\delta_{c}(i)\right)\right\}
\end{aligned}
$$

次に，各材料の限界 CTOD 值の確率分布を仮定する。限界

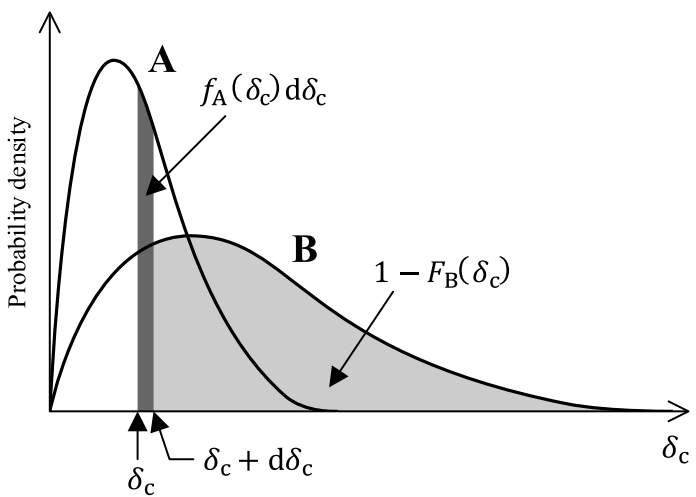

Fig. 2 Probability density functions of critical CTOD for material $\mathrm{A}$ and $\mathrm{B}$ 
CTOD 值はワイブル分布に従うことが多くの実験によって 確認されているので ${ }^{21)}$, 本研究でもそれを採用することと する.

$F_{A}\left(\delta_{c}\right)=1-\exp \left[-\left(\frac{\delta_{c}}{b_{A}}\right)^{m_{A}}\right], \quad F_{B}\left(\delta_{c}\right)=1-\exp \left[-\left(\frac{\delta_{c}}{b_{B}}\right)^{m_{B}}\right]$

(4) 式は, 上式の両分布の母数 $m_{A}, b_{A}, m_{B}, b_{B}$ を変数とする尤度 関数と考えることができる $\left(L=L\left(m_{A}, b_{A}, m_{B}, b_{B}\right)\right)$. 本問題は, 与えられた $N$ 本の実験結果の下でこの関数を最大とするよ うに母数を決定することに帰着される。

\section{3. モンテカルロ・シミュレーションによる妥当性検証}

\section{1 計算方法}

前章で提案した手法の妥当性を溶接継手 CTOD 試験で検 証するためには膨大な実験を必要とする上，実験誤差が含 まれうる。そこで，モンテカルロ・シミュレーションによ る数值実験による検証を試みることとした.

まず，次の手順によって $N$ 個の限界 CTOD 值を得る.

（1）両材料の限界 CTOD 值ワイブル分布の形状母数と尺度 母数 $m_{A}, b_{A}, m_{B}, b_{B}$ を仮定する.

（2）上記分布に従い，両材料の限界 CTOD 值をランダムに 1 個づつ発生させる。

（3）両材料の限界 CTOD 值を比較して小さいほうの值をそ の試験片 (Fig. 1) の限界 CTOD 值 $\delta_{\mathrm{c}}(i)$ として採用する. また，限界 CTOD 值が小さいほうの材料（A または B） を破壊が発生した材料として記録する。

（4）上記の (2)〜(3) を $N$ 回繰り返すことによって, $N$ 個の限 界 CTOD 值と破壊が発生した材料のデータを得る。

次に, 上記の手順で得られたデー夕を基に, (4) 式の尤度関 数が最も大きくなる母数 $m_{A}, b_{A}, m_{B}, b_{B}$ の組を探す. (4) 式は両 材料の母数に関して変数分離型であるので，その最大化に あたり両材料の母数を独立に求めてもよい. また，(4) 式を最 大化する際，その対数を最大化してもよい. 本論文では, 数学計算ソフトウェア Mathematica ${ }^{\circledR 26)}$ の組み込み関数を使
用して尤度関数の最大化を行った。 なお，以下に示す計算 では，断らない限り，両材料限界 CTOD 值分布の形状母数 として同じ值を仮定しており，実際に最適化したパラメー 夕は尺度母数のみである.

比較のために，以下の 2 とおりの方法でも母数を推定し て本提案法との比較を行った。

比較法 $\mathrm{a}$ ：材料 $\mathrm{A}$ から破壊が発生した試験片の限界 CTOD 值（ $N_{A}$ 本）のみを用い，ワイブル確率紙上にデ ータをプロットし，最小二乗法により直線回帰して材 料 A の限界 CTOD 值ワイブル母数を求める. 同様に, 材料 B に対してもワイブル母数を求める.

比較法 b：材料 A と B を区別せず $\left(N=N_{A}+N_{B}\right.$ 本 $)$, 限 界 CTOD 值をワイブルプロットして最小二乗法により ワイブル母数を求める.

\section{2 計算結果}

Table 1 に計算条件を示す.まず, 上記の限界 CTOD 值のデ ータを得る計算手順の確認を行うための計算を行った（Case 1). 両材料の限界 CTOD 值の形状母数を $m_{A}=m_{B}=2$ とし, 尺度母数の比を $b_{A}=b_{B}=2$ とした。 また，計算誤差を出来 るだけ小さくするために，N=10,000 とした．材料 A（破壊 しやすい側）から破壊が発生したものは 8,030 本，材料 B （破壊しにくい側）から破壊が発生したものは 1,970 本であ った. 破壊発生割合の理論值は 0.8:0.2であり（Appendix 参 照)，本計算手法は妥当と考えられる，次に，最尤推定法の 計算手順の妥当性を同条件で確認した。材料 A および材料 B それぞれの計算結果を Fig. 3 に示す. 本提案法では，尺度 母数のみを変数とした場合 $\left(m_{A}=m_{B}=2\right.$ を仮定, 図中の

Table 1 Conditions for Monte-Carlo simulations

\begin{tabular}{c|c|c|c|c|c|c|c}
\hline \multirow{2}{*}{ Case } & \multicolumn{2}{|c|}{ Material A } & \multicolumn{2}{c|}{ Material B } & \multirow{2}{*}{$b_{\mathrm{B}} / b_{\mathrm{A}}$} & $N$ & $\begin{array}{c}\text { Num. } \\
\text { of trials }\end{array}$ \\
\cline { 2 - 7 } & $m_{\mathrm{A}}$ & $\begin{array}{c}b_{\mathrm{A}} \\
{[\mathrm{mm}]}\end{array}$ & $m_{\mathrm{B}}$ & $\begin{array}{c}b_{\mathrm{B}} \\
{[\mathrm{mm}]}\end{array}$ & & & \\
\hline 1 & 2 & 0.1 & 2 & 0.2 & 2 & 10,000 & 1 \\
\hline 2 & 2 & 0.1 & 2 & 0.2 & 2 & 100 & 1,000 \\
\hline 3 & 2 & 0.1 & 2 & 0.2 & 2 & 20 & 1,000 \\
\hline 4 & 2 & 0.1 & 2 & 0.1 & 1 & 10,000 & 1,000 \\
\hline 5 & 1.5 & 0.1 & 1.5 & 0.2 & 2 & 10,000 & 1,000 \\
\hline
\end{tabular}
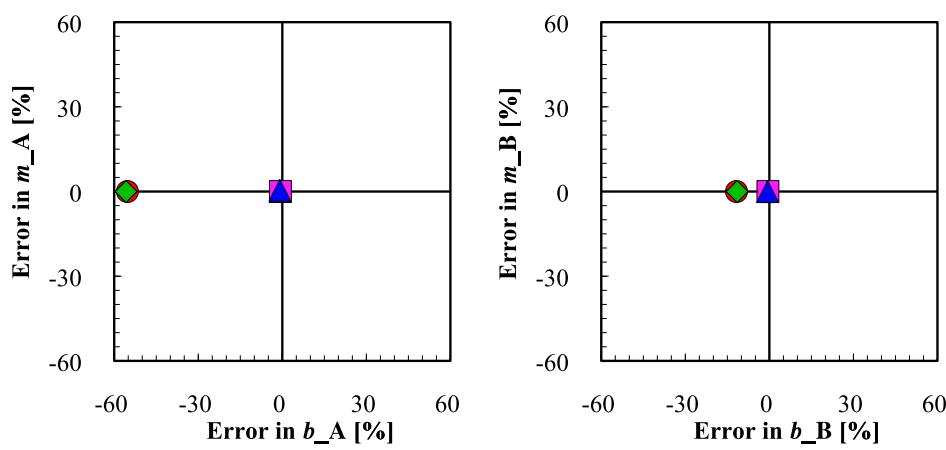

$\square$ Present model (one parameter)
$\Delta$ Present model (two parameters)
- Comparative a
$\diamond$ Comparative b

Fig. 3 Result of simulation in Case 1 

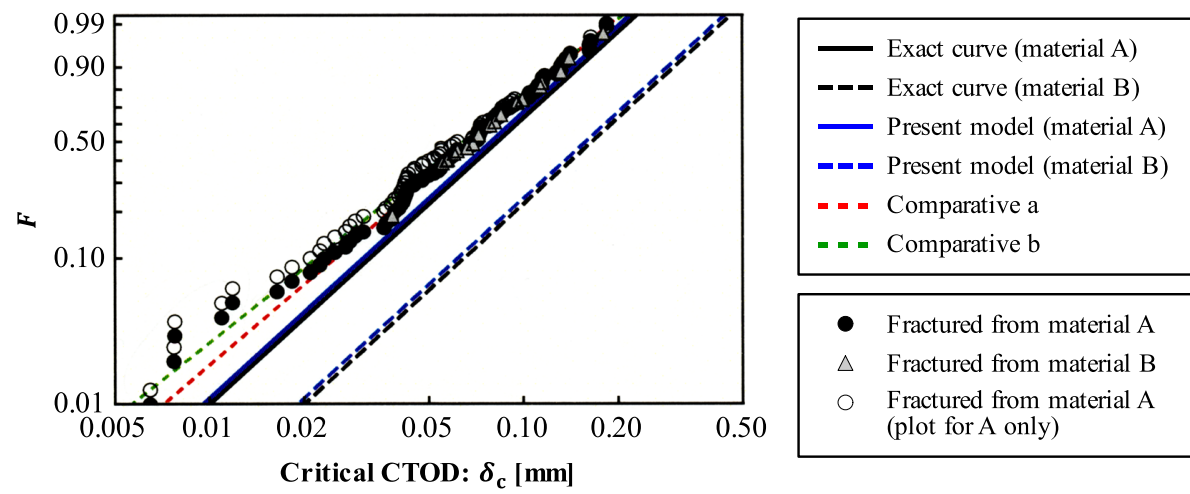

Fig. 4 Result of simulation in Case 2

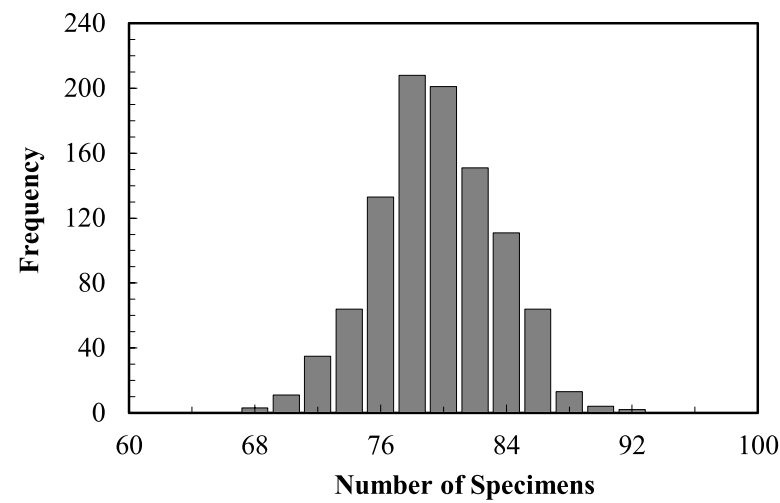

Fig. 5 Number of specimens having fracture initiation from material A in Case 2

“one parameter”）に加えて形状母数と尺度母数をともに変数 とした場合 (図中の “two parameters”) の計算も行ったが, 両 者ともに仮定した值に極めて近い值が得られた． $b_{B} / b_{A}$ の值 を変化させても同様な結果であった.この結果から，上記 の計算手順は妥当であることが確認された. なお, 比較法 $\mathrm{a}$, b については尺度母数の予測值は仮定した值から乘離した。

次に, Case 2 の条件に対して計算を行った. $N=100$ とし, 1,000 回の試行を行った. Fig. 4 に, ある 1 回の試行によって 得られた限界 CTODの分布を示す。この場合，材料 A から 破壊が発生した試験片の本数は丁度, 80本, 材料 B から破 壊が発生した試験片は20本であった。まず，比較法 a では， 材料 A から破壊した80本のみのデータをプロットして直線 回帰すると点線のようになり，材料 A で仮定した直線より

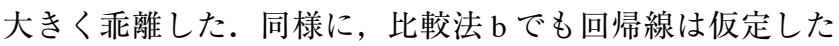
直線より乘離した。一方, 本提案法では, 仮定した直線に 近い結果が両材料で得られた。

Fig. 5 に, Case 2 において材料 A で破壊が発生した試験本 数の分布を示す. 理論值の80本を中心とした分布を示して おり，妥当な限界 CTOD 值分布が得られていることが確認 できる. Fig. 6 (a) および Fig. 6 (b) に, 各々, 材料 A および B に対する尺度母数の予測結果を示す，横軸は, 両材料で仮 定した尺度母数で無次元化してある．まず，材料 A につい て，本提案法で予測した尺度母数は仮定した值を中心に分

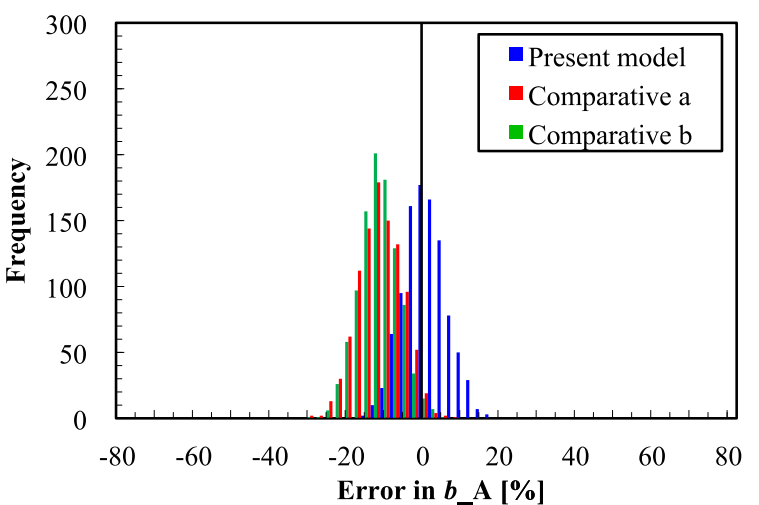

(a) Material $\mathrm{A}$

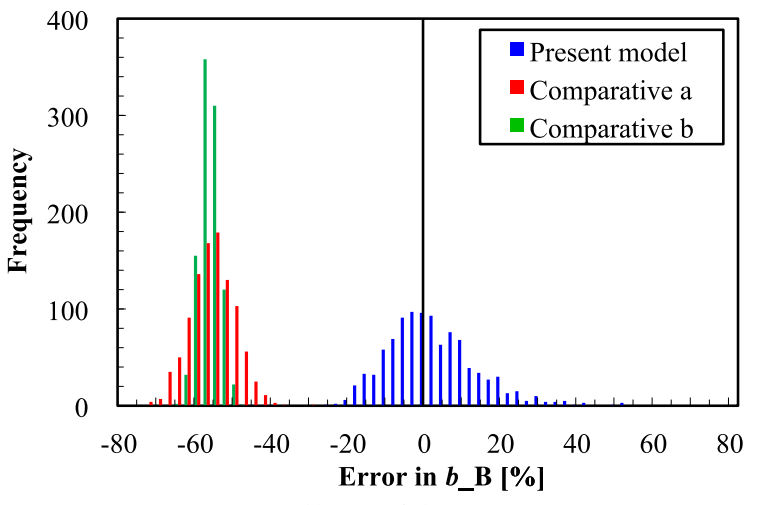

(b) Material B

Fig. 6 Comparison of the predicted and assumed value of scale parameter in Case 2

布しており，妥当な予測がされていることが確認できた. 一方，比較法 $\mathrm{a}$ と $\mathrm{b}$ では，仮定した值よりも低い值を予測 していることは明らかである。材料 A から破壊が発生した 試験片の限界 CTOD 值だけを使って尺度母数を計算すると (比較法a), 実際よりも低い值を予測してしまうことが分 かる.これは，材料 B から破壊が発生した試験片におい て，その試験片の限界 CTOD 值のレベルに達するまで材料 A から破壊が発生しなかったという情報を無視しているた めである．同様に，破壊しにくい材料 B も含めて全試験デ 一タで尺度母数を求めると（比較法 $\mathrm{b}$ ), 仮定した值よりも 低く予測してしまうことが分かる. Fig. 6(b) から，材料 B に 


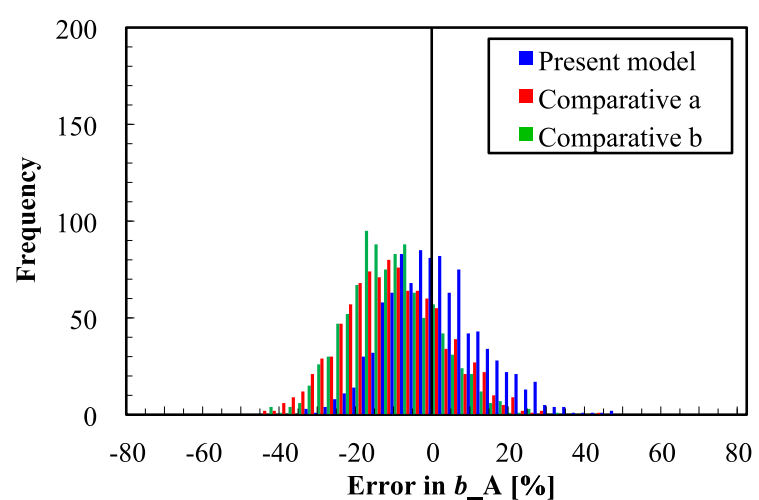

(a) Material $\mathrm{A}$

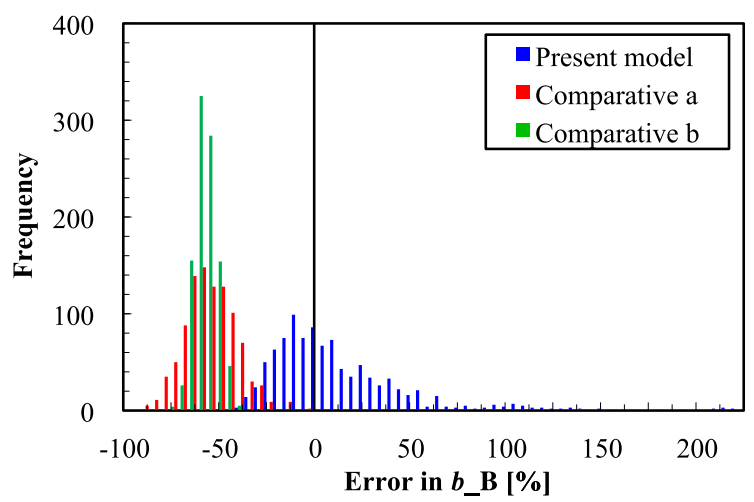

(b) Material B

Fig. 7 Comparison of the predicted and assumed value of scale parameter in Case 3

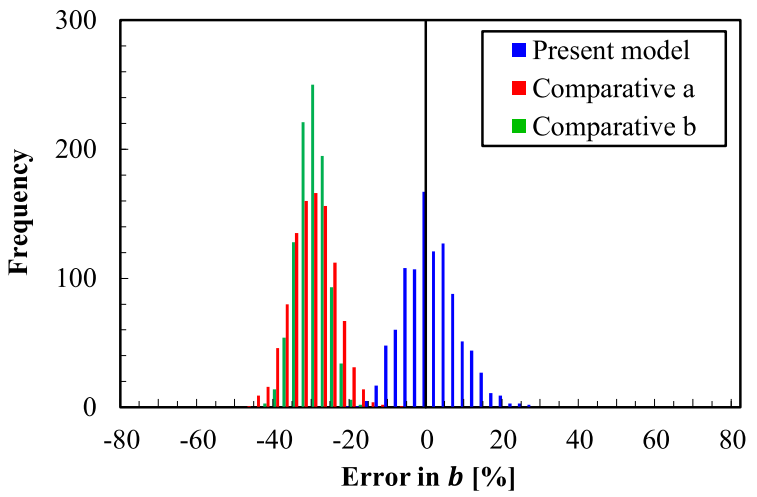

Fig. 8 Comparison of the predicted and assumed value of scale parameter in Case 4

対しても同様な傾向を読み取ることができる。ただし，材 料 B から破壊が発生する試験本数が少ないことを反映し て，予測值の変動は材料 A の場合よりも大きくなった.

Fig. 7 (a)，(b) に，試験本数を $N=20$ とした Case 3 の計算結 果を示す. 試験本数が少なくなると, 尺度母数の予測精度 は低下し，特に，材料 A に対しては比較法に対する本提案 法の優位性は小さくなる。しかしながら, 材料 B については 本提案法による推定は仮定した值を中心に分布しており，比 較法 $\mathrm{a}, \mathrm{b}$ よりも妥当な予測をしていることが分かる。ただ し,材料 B では確率は低いながらも值の大きいほうに大き く乘離した予測をする場合があるので, 注意が必要である.

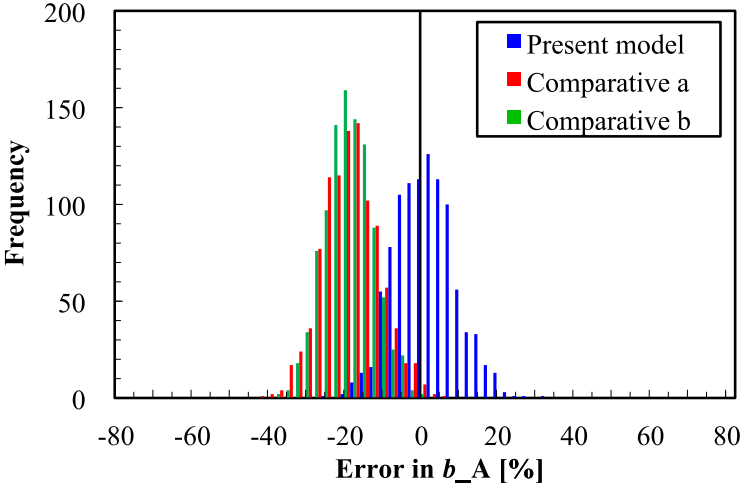

(a) Material $\mathrm{A}$

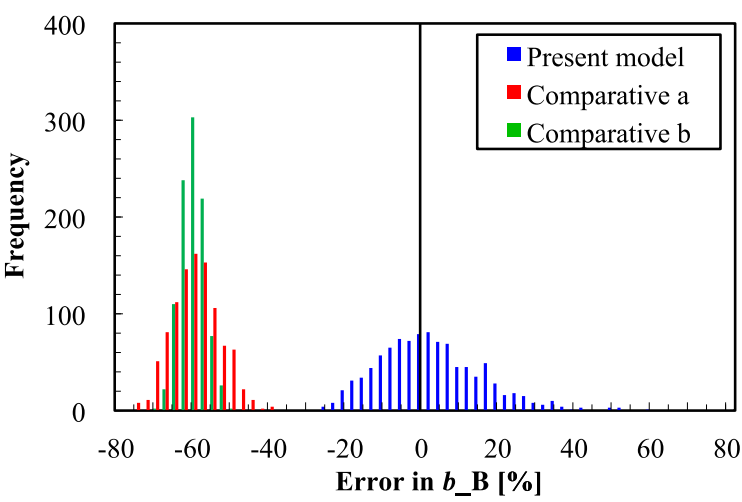

(b) Material B

Fig. 9 Comparison of the predicted and assumed value of scale parameter of material $\mathrm{A}$ in Case 5

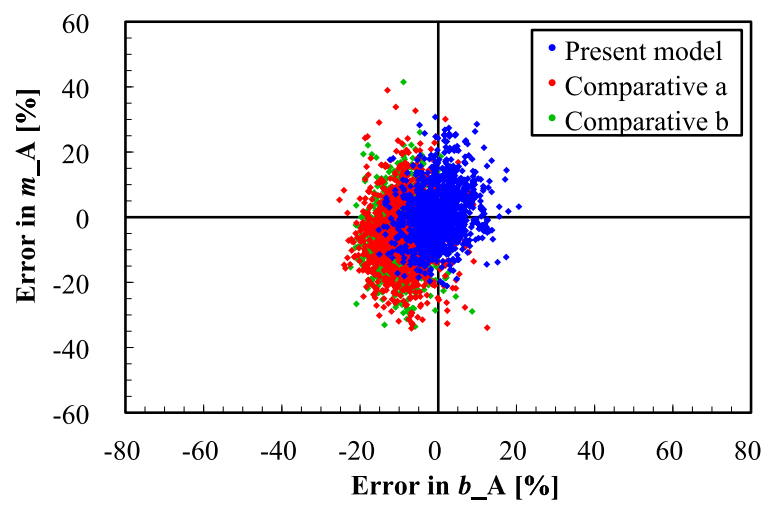

(a) Material A

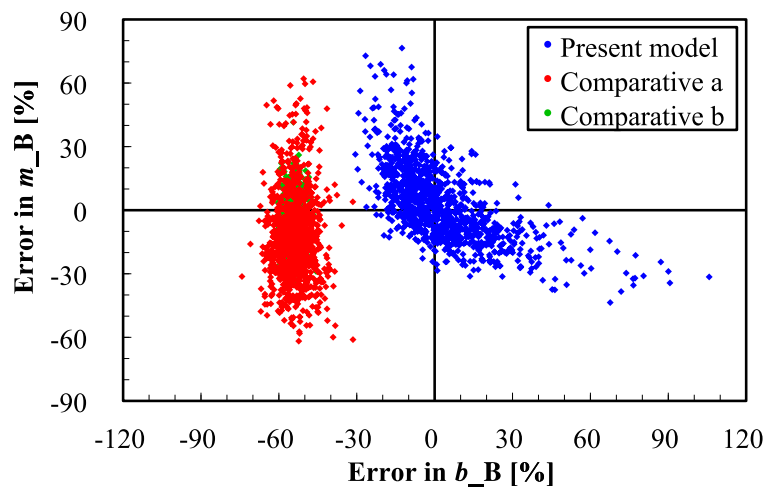

(b) Material B

Fig. 10 Distributions of the predicted value of shape and scale parameters in Case 2 
Fig. 8 に, 材料 A と材料 B の尺度母数を同一とした場合 （Case 4）の計算結果を示す.この場合にも本提案法は妥当な 予測結果を与えていることが確認できる。一方, 比較法 $\mathrm{a}$ と b では, 仮定した值よりも大幅に低いほうに予測值が分 布していることが分かる．上述のとおり，片方の材料（た とえば材料 A）の限界 CTOD 值だけを取り出して尺度母数 を求めると, 仮定した值よりも低い值を予測してしまうこ とはこの条件でさらに明確である．無視した約半数の試験 片（材料 B から破壊発生）において，材料 A はその限界 CTOD 值まで破壊を免れたという情報を無視しているため によって生じる誤差である. なお, 試験本数を少なくした場 合も計算を行ったが, 傾向は同様であったので, 省略する.

Fig. 9 に, 両材料の形状母数を $m_{A}=m_{B}=1.5$ とした場合の 計算結果を示す. Fig. 6 (a) に比べて, 限界 CTOD のばらつき が大きいことを反映して予測の変動が大きくなるものの, こ の場合にも本提案法が有効であることがわかる.

上記の計算では, 両材料の形状母数を既知のものとして 計算を行った. しかしながら, Fig. 4 からも明らかなとおり， 全試験片の限界 CTOD 值の形状母数は各材料のそれとは值 が異なり，元の材料の形状母数は未知である。 そこで，両 材料の形状母数もパラメータとした場合の計算を Case 2 に ついて実施した. Fig. 10 に, 材料 A および B それぞれに対す る母数の予測結果を示す. 本提案法では両母数ともに仮定 した值を中心に変動しているのに対して，比較法 $\mathrm{a}, \mathrm{b}$ では 形状母数を低目に予測していることがわかる. 破壊限界值 レベルが異なる材料の混合によって限界 CTOD のばらつき が大きくなっていることを反映しているためである.

\section{4. 考察}

局所脆化域を含む溶接 HAZ の CTOD 試験においては，局 所脆化域だけでなくそれ以外の組織からも脆性破壊が発生 することが一般的である。この場合, 局所脆化域単独の限 界 CTOD 值の分布を求めることは困難であった. 本論文で 提案する方法はこの問題に対してひとつの解決方法を提供 するものと考えることができる，上述のように，溶接部の 限界 CTOD 值の分布に及ぼす影響は多岐に亘っており, 疲 労亀裂前縁に占める組織の分率は特に重要である ${ }^{9)}$. 局所脆 化域が亀裂前縁にサンプリングされる度合いによって限界 CTOD 值は大きく変化する. 継手 CTDO 試験において粗粒 HAZ が隹裂前縁に占める割合が $15 \%$ 以上と規定されたのは そのためである ${ }^{11)}$. しかしながら，粗粒 HAZ が亀裂前縁を 占める割合がある值以上でも, 限界 CTOD 值は大きくばら つく. 本論文で対象とするのはこのような状況を対象とす るものであり, 粗粒 HAZ サンプリングの度合いが変化する ことによる限界 CTOD 值の変動を対象とするものではな い. 後者の問題を定量的に評価するためにはワイブル応力 による解析などが必要である．粗粒 HAZ 限界ワイブル応力 の分布を CTOD 試験結果と有限要素法 (FEM) の組み合わ
せによって求めようとする場合，粗粒 HAZ だけから脆性破 壊が発生した試験片の限界 CTOD 值の分布が必要である. 他のミクロ組織からも脆性破壊が発生した試験結果から粗 粒 HAZ 単独の限界 CTOD 值を分離予測することが本提案 手法で可能となる。

Case 4 では，材料 A と B が同一の限界 CTOD 值の分布を 有する場合を取り扱った。本提案法では妥当な予測を与え るのに対して, 比較法 $\mathrm{a}$ と $\mathrm{b}$ では仮定した尺度母数から大 きく乘離した予測をしてしまうことが示された. Case 4 は, 材料 A と B がミクロ組織的に同一で均一な材料の CTOD 試 験を対象としたことを必ずしも意味するものではない．た とえば，材料 A はミクロ組織的に勒性が低くても亀裂前縁 に占める割合が低ければ，両材料の限界 CTOD 值の分布が 等しくなることがありうる。このような場合も含めて，当 該材料から破壊が発生した限界 CTOD 值データだけを用い て尺度母数を推定することは妥当ではない.このような単 純な取り扱いは，特に両材料の限界 CTOD 值分布が拮抗す る場合に誤差が大きくなる可能性があるので，本提案法に よる予測が必要となる.

逆に，片方の材料から破壊が発生する割合が圧倒的に高 い場合には，本提案法に依るまでもなく，比較法 a によっ て尺度母数を予測しても大きな誤差は生じないと考えるこ とができる．破壊が発生しないほうの材料はデー夕数は自 ずと小さくなるので，本提案法でも予測誤差は大きくなる.

溶接 HAZ の CTOD 試験において，疲労亀裂前縁が粗粒 HAZ，再加熱粗粒 HAZ，細粒 HAZ，溶接金属，母材と多 岐に亘る組織をサンプリングしている場合でも，局所脆化 域をたとえば粗粒 HAZ と再加熱粗粒 HAZ に限定し，それ 以外の組織をまとめて, 両者の限界 CTOD 值分布がある確 率分布に従うものと近似できるのであれば，本提案法の適 用において必ずしも全組織を独立に扱う必要はなく，2 材 料として扱うことが可能と考えられる.

本提案法の妥当性を実継手の CTOD 試験によって検証す ることは困難と言わざるを得ない。たとえば，異なる条件 （局所脆化域サンプリング割合，溶接部強度分布）などが異 なる試験によって，本提案法と FEM との組み合わせによっ て限界ワイブル応力を求めて比較するなど，間接的な方法 によって検証する必要があろう。

\section{5. 結言}

溶接継手 CTOD 試験において, 亀裂前縁に占めるミクロ 組織が複数存在する場合, 局所脆化域単独の限界 CTOD 值 分布を求めることが必要となる場合がある.このような問 題に対する検討を実施した結果，以下のような結論を得た。

（1）亀裂前縁に占める組織を，問題とする組織とそれ以外 の組織に分けて，各々の限界 CTOD 值の分布が特定の 確率分布に従うと仮定できる場合, 複数本の CTOD 試 験の情報（限界 CTOD 值と破壊が発生した組織）か 
ら，(4) 式の尤度関数を最大化するように両確率分布の 母数を予測する方法を提案した.

（2）提案手法の妥当性を，モンテカルロ・シミュレーショ ンを用いた数值実験によって検証し，その有効性を確 認した。

今後，本提案法の実溶接継手 CTOD 試験などへの適用が 期待される.

\section{Appendix：各材料から破壊が発生する割合}

材料 A から破壊が発生する確率は次式で与えられる.

$$
P_{A}=\int_{0}^{\infty} f_{A}\left(\delta_{c}(i)\right)\left\{1-F_{B}\left(\delta_{c}(i)\right)\right\} d \delta_{c}
$$

限界 CTOD 值の分布が (5) 式で表される場合，上式は以下の ようになる。

$$
P_{A}=\int_{0}^{\infty} \frac{m_{A}}{b_{A}}\left(\frac{\delta_{c}}{b_{A}}\right)^{m_{A}-1} \exp \left[-\left(\frac{\delta_{c}}{b_{A}}\right)^{m_{A}}\right] \exp \left[-\left(\frac{\delta_{c}}{b_{B}}\right)^{m_{B}}\right] d \delta_{c}
$$

この式は積分できて,$m_{A}=m_{B}=m$ の場合は以下のとおりと なる.

$$
P_{A}=-\left.\frac{\exp \left[-\left(\frac{1}{b_{A}^{m}}+\frac{1}{b_{B}^{m}}\right) \delta_{c}^{m}\right]}{b_{A}^{m}\left(\frac{1}{b_{A}^{m}}+\frac{1}{b_{B}^{m}}\right)}\right|_{0} ^{\infty}=\frac{\left(b_{B} / b_{A}\right)^{m}}{1+\left(b_{B} / b_{A}\right)^{m}}
$$

$$
\text { 謝辞 }
$$

本研究は, (社) 日本造船工業会造船学術研究推進機構の 助成により実施されたものである，記して感謝の意を表す．

\section{参 考 文 献}

1) R. E. Dolby, "Welding and fracture initiation in QT low alloy steels", Metal Construction and British Welding Journal, March 1971, p.99-103.

2) G. G. Saunders, "Influence of welding and postweld heat treatment on the heat-affected zone fracture toughness of carbon-manganese and low-alloy steels", The Iron and Steel Institute Biennial Conference on Heat Treatment, 8-9, Dec. 1971, p.32-42.

3) R. E. Dolby, G. G. Saunders, "Metallurgical factors controlling the HAZ fracture toughness of carbon: manganese and low alloy steels", The Iron and Steel Institute Biennial Conference on Heat Treatment, 8-9, Dec. 1971, p.43-66.

4) R. E. Dolby, J. F. Knott, "Toughness of martensitic and martensiticbainitic microstructures with particular reference to heat-affected zones in welded low-alloy steels", J. Iron and Steel Institute, Nov. 1972, pp.857-865.

5) 貝原正一郎，村山武弘，河野武亮，深川宗光：低温用鋼溶接 部の限界 COD 值のばらつきに関する一考察, 溶接学会論文 集, vol.2, (1984), No.1, pp.104-112.

6) 貝原正一郎, 村山武弘, 河野武亮, 南二三吉, 豊田政男, 佐 藤邦彦：低温用鋼溶接継手の破壊強度評価への曲げ限界 COD
值の意義について，溶接学会論文集，vol.4，(1986)，No.1， pp.178-181.

7) 土師利明, 粟飯原周二, 萩原行人, 川島喜樹果, 内野耕一, 冨田幸男，千々岩力雄，引張強度 $50 \mathrm{kgf} / \mathrm{mm} 2$ 級高張力鋼溶接 熱影響部の限界 CTOD に及ぼす局所脆化域の影響，鉄と鋼， 第74年（1988），第6号，pp.1105-1112.

8) P. L. Harrison, D. J. Abson, A. R. Jones, D. J. Sparks, Fractographic and metallographic study of the initiation of brittle fracture in weldments", ASTM STP 1085, American Society of Testing and Materials, 1990, pp.102-122.

9) D.P.Fairchild, "Fracture toughness testing of weld heat-affected zones in structural steels", ASTM STP 1058, American Society for Testing and Materials, 1990, pp.117-141.

10）豊貞雅宏，萩原行人，野原和宏，大塚隆夫，溶接継手限界 CTODとその板厚効果について，日本造船学会論文集，第 159 号, 1986, p.330-339

11) API RP2Z, Recommended practice for preproduction Qualification for steel plates for offshore structures, first edition, May 1987.

12) S. Machida, H. Yoshinari and Y. Suzuki, A Statistical Study on the Effect of Local Brittle Zones (LBZs) on the Fracture Toughness (Crack Tip Opening Displacement) of Multipass Welded Joints, Fracture Mechanics 24, ASTM STP 1207, 1994, pp. 264-290.

13) 梶本勝也, 谷光夫, 佐藤伸明, 厚板溶接部の COD 試験法に 関する研究, 溶接学会論文集, 第 4 巻 (1986), 第 1 号, pp.182-186.

14) S. Machida, T. Miyata, M. Toyosada, Y. Hagiwara, Study of methods for CTOD testing of welds, ASTM STP 1058, American Society for Testing and Materials, 1990, pp.142-156.

15）土師利明, 粟飯原周二, 萩原行人, 内野耕一, 川島喜樹果, 冨田 幸男, 千々岩力雄，高張力鋼限界 COD 值に及ぼす諸影響因 子の検討, 日本造船学会論文集, 第 162 号, 1988, p.447-455.

16) M. G. Dawes, H. G. Pisarski, S. J. Squirrell, Fracture mechanics tests on welded joints, ASTM STP 995, American Society of Testing and Materials, 1989, pp.191-213.

17）豊田政男，南二三吉，溶接 HAZ 勒性評価のための CTOD 試 験片採取のあり方，日本造船学会論文集，第 169 号，1991， p.279-287.

18) ISO 15653-2011: Metallic materials - Method of test for the determination of quasistatic fracture toughness of welds.

19）佐藤邦彦，豊人生田政男，南二三吉，溶接部のへき開発生限 界値のばらつきに関する確率論的検討，溶接学会論文集，第 2 巻 (1984)，第 3 号, pp.440-447.

20）佐藤邦彦，豊田政男，南二三吉，最弱リンクモデルに基づく 溶接部の局部劣化部勒性推定法, 溶接学会論文集, 第 3 巻 (1985)，第 1 号，pp.82-89.

21) F. M. Beremin, A local criterion for cleavage fracture of a nuclear pressure vessel steel, Metallurgical Trans. vol. 14A, 1983, pp.22772287.

22) 南二三吉, Claudio Ruggieri, 大畑充, 豊田政男, ローカルアプロ 一チの適用によるぜい性破壊発生限界に及ぼす試験片形状 · 寸法の影響の評価, 材料, vol.45, No.5, pp.544-551, 1996.

23) F. Minami, M. Ohata, M. Toyoda, K. Arimochi, S. Suzuki, K. Bessyo, C. Thaulow, M. Hauge, Prediction of specimen geometry effect on fracture resistance of HAZ-notched welds by the local approach, proc. Mis-Matching of Interfaces and Welds, 1977, GKSS Research Center Publications, Geesthacht, FRG, pp.319-330.

24）大畑充，南二三吉，豊田政男，ローカルアプローチの適用に よる強度ミスマッチを有する溶接継手の熱影響部破壊勒性評 価，日本造船学会論文集，第 180 号，1996，p.565-573.

25） 三村宏，島貫広志，小林順一，大城隆吉，溶接継手部の破壊 勒性のバラツキ，圧力技術，vol.34，No.4，1996，pp.231-238。

26) Wolfram Research, Mathematica. 